\title{
QUALITY OF LIFE AND SLEEP IMPAIRMENT IN CHRONIC COCAINE DEPENDENTS
}

\author{
Adriana Lima', Sueli Rossini', Rubens Reimão ${ }^{2}$
}

\begin{abstract}
Objective: To evaluate quality of life (QL) and sleep quality impairment of cocaine chronic dependents in use of cocaine. Method: 40 patients, chronic cocaine dependents were evaluated ( $37 \mathrm{M} ; 3 \mathrm{~F}$ ), with mean age of 28.92 years, along with 40 controls paired for gender and age. The following instruments were used: a) the semi-structured clinical interview; b) the Brazil Economic Classification; c) the Pittsburgh Sleep Quality Index; d) World Heath Organization Quality of Life-BREF (WHOQOL-BREF). Results: The cocaine dependents showed QL impairment, with deficits in the physical, psychological and social relations domains. Impaired sleep quality was also observed in the cocaine dependents. However, the QL impairment was not directly due to sleep deficit. Conclusion: Chronic cocaine dependents showed impairment in QL and sleep impairment. However, for the cocaine dependent group, sleep impairment was not regarded as compromising QL probably because cocaine, rather than sleep, was the main factor negatively influencing $\mathrm{QL}$.
\end{abstract}

KEY WORDS: cocaine, sleep, sleep disorders, quality of life.

\section{Qualidade de vida e comprometimento do sono em dependentes crônicos de cocaína}

Resumo - Objetivo: Avaliar a qualidade de vida (QV) em dependentes de cocaína na fase de uso de droga e comprometimento da qualidade do sono. Método: Foram avaliados 40 pacientes dependentes de cocaína ( $37 \mathrm{M} ; 3 \mathrm{~F}$ ), com média de idade de 29,92 anos; e 40 controles, equiparando-se as variáveis de gênero e idade e utilizando-se os seguintes instrumentos: a) Entrevista clínica semi-dirigida; b) Classificação Econômica Brasil; c) Índice de Qualidade do Sono de Pittsburgh; d) World Health Organization Quality of Life-BREF (WHOQOLBreve). Resultados: Os dependentes de cocaína apresentaram prejuizo na QV, com alterações nos domínios físico, psicológico e também das relações sociais. No grupo estudo não houve associação entre $Q V$ e qualidade do sono, ou seja, para os sujeitos desta amostra, a qualidade do sono não afetou a QV. Conclusão: No grupo estudo a QV foi considerada prejudicada, mas não devida de forma primordial ao comprometimento da qualidade do sono. Nestes pacientes a cocaína é provavelmente o fator primordial negativo sobre a $\mathrm{QV}$ e não o comprometimento do sono.

PALAVRAS-CHAVE: cocaína, sono, distúrbios do sono, qualidade de vida.

Chronic sleep disorders may impair quality of life (QL). Several population studies have shown that 10 to $15 \%$ of people with chronic sleep disorders are also drug abusers'. The chronic use of drugs that cause euphoria or changes in consciousness may lead to reduced $\mathrm{QL}^{2}$. The chronic use of cocaine or crack, in addition to higher mortality, leads to reduction in life expectancy, and several socioeconomic effects due to higher rates of hospitalization, underemployment, unemployment, and numerous other impairments such as personal suffering, isolation, stigma, and familial disengagement ${ }^{2}$.

The excessive and continuous use of high doses of stimulant drugs such as cocaine is also linked to inadequate social behavior and anti-social behavior. As the administration of this drug is self-inflicted, the behavioral consequences are often not perceived as a problem. Therefore, chronic central nervous system stimulants abusers are generally brought for medical assistance by family or friends ${ }^{3}$.

The objective of this study was to evaluate the perception of QL in chronic cocaine dependents and of sleep impairment. This study was part of a larger project on cocaine abusers sleep patterns and disorders to be published elsewhere.

\section{METHOD}

This research was performed within the Bairral Psychiatry In-

\footnotetext{
Sleep Medicine Advanced Research Group, Division of Clinical Neurology, Hospital das Clínicas, University of São Paulo Medical School, São Paulo SP, Brazil: 'Psychologist; ${ }^{2}$ Neurologist, MD, PhD. Funding: CAPES.
}

Received 8 August 2008. Accepted 6 October 2008.

Dr. Rubens Reimão - Rua dos Bogarís 38 - 04047-020 São Paulo SP - Brasil.E-mail: reimaorubensneuro@yahoo.com 
stitute, in São Paulo State, a center dedicated to inpatients treatment of chronic chemical dependence in private of health-plan clients. Forty patients ( $37 \mathrm{M} ; 3 \mathrm{~W}$ ), with mean age of 28.92 years, from 18 to 60 years' olds, of both genders, and with cocaine dependence according to the criteria of the ICD- $X^{4}$ were included.

The control group was composed of 40 health professionals that worked in the hospital, on morning and afternoon shifts, and had no complaints regarding use or abuse of psychoactive drugs.

The following instruments were used: the semi-structured clinical interview; the Brazil Economic Classification ${ }^{5}$; the Pittsburgh Sleep Quality Index (PSQI) ${ }^{6}$ and the World Health Organization Quality of Life-BREF (WHOQOL-BREF) ${ }^{7,8}$.

Data obtained was evaluated by means of Fisher's exact test and the chi-square test, and the Mann-Whitney test were used to ascertain statistical value where $p<0.005$ was considered the significant.

This research was approved by the Ethics Committee of the Hospital das Clínicas, University of São Paulo Medical School under the number 08/05. All patients and controls signed the informed consent.

\section{RESULTS}

The study group was composed predominantly males $(92 \%)$ with with eight schooling years (32.5\%), from medium to upper social classes, bachelors, divorced or separated $(72.5 \%)$ and actives in occupational terms as students (52.5\%). The control group was paired with the study group for the variables described.

Table 1 shows data related to the perception of QL in the study group and control group. The means in the study group for physical, psychological and social relation domains were significantly different $(p<0.001)$ compared to the control group. The study group showed lower QL scores than the control group, except for the environment domain $(p=0.137)$.

With regards to the global perception of sleep on the PSQI and its association to QL, no statistically significant difference was found ( $p>0.05$ ) (Table 2).

In the control group, the subjects with better sleep quality showed higher QL scores. Scores on the physical domain of QL proved higher among subjects evaluated as good sleepers.

Table 1. QL perception of study and controls group in domains of the WHOQOL.

\begin{tabular}{llccccc}
\hline Domains & Group & Mean & Min & Max & N & P \\
\hline Physical & Study & 12 & 7 & 17 & 40 & $<0.001$ \\
& Control & 18 & 10 & 20 & 40 & \\
Psychological & Study & 13 & 5 & 18 & 40 & $<0.001$ \\
& Control & 16 & 11 & 20 & 40 & \\
Social relations & Study & 12 & 5 & 16 & 40 & $<0.001$ \\
& Control & 16 & 8 & 20 & 40 & \\
Environment & Study & 14 & 7 & 18 & 40 & 0.137 \\
& Control & 14 & 11 & 18 & 40 & \\
\hline
\end{tabular}

$\mathrm{p}=$ Mann-Whitney test.

Table 2. Comparison between QL and PSQI scores for study and control groups.

\begin{tabular}{|c|c|c|c|c|c|c|c|c|}
\hline \multirow{2}{*}{$\begin{array}{l}\text { WHOQOL } \\
\text { domain }\end{array}$} & \multicolumn{4}{|c|}{ Study group } & \multicolumn{4}{|c|}{ Control group } \\
\hline & PSQI & $\mathrm{n}$ & Median & $\mathrm{p}$ & PSQI & $\mathrm{n}$ & Median & $\mathrm{p}$ \\
\hline \multirow[t]{3}{*}{ Physical } & $<5$ & 3 & 15 (11-17) & 0.320 & $<5$ & 25 & $18(11-20)$ & 0.009 \\
\hline & $>5$ & 37 & $12(7-17)$ & & $>5$ & 15 & 17 (10-18) & \\
\hline & Total & 40 & $12(7-17)$ & & Total & 40 & $18(10-20)$ & \\
\hline \multirow[t]{3}{*}{ Psychological } & $<5$ & 3 & $13(10-16)$ & 0.962 & $<5$ & 25 & $17(12-20)$ & 0.063 \\
\hline & $>5$ & 37 & $13(5-18)$ & & $>5$ & 15 & 15 (11-17) & \\
\hline & Total & 40 & $13(5-18)$ & & Total & 40 & $16(11-20)$ & \\
\hline \multirow[t]{3}{*}{ Social relations } & $<5$ & 3 & $13(12-16)$ & 0.273 & $<5$ & 25 & $17(8-20)$ & 0.103 \\
\hline & $>5$ & 37 & $12(5-16)$ & & $>5$ & 15 & $15(12-20)$ & \\
\hline & Total & 40 & $12(5-16)$ & & Total & 40 & $16(8-20)$ & \\
\hline \multirow[t]{3}{*}{ Environment } & $<5$ & 3 & 15 (14-18) & 0.175 & $<5$ & 25 & 15 (11-18) & 0.640 \\
\hline & $>5$ & 37 & 14 (7-17) & & $>5$ & 15 & $14(11-18)$ & \\
\hline & Total & 40 & $14(7-18)$ & & Total & 40 & $14(11-18)$ & \\
\hline
\end{tabular}

$\mathrm{p}=$ Chi-square test. 


\section{DISCUSSION}

Comparison between study and controls revealed a marked QL impairment in the chronic cocaine users, on the physical as well as psychological and social relations domains. This impairment may have been caused by inactivity, as well as by lack of appetite, or simply reflect the psychological context of having recently become aware of their incapacitation by a disease with potentially severe consequences.

Chemical dependency is a chronic and recurrent disorder characterized by the search for, and compulsive consumption of drugs. The presence of a chronic disease is associated to lower QL since patients are more strongly influenced by self-evaluation mechanisms involving the meaning of being sick than their actual condition.

It should be stressed that to our best effort no similar studies were found in the literature addressing QL and sleep impairment in cocaine dependents because stimulant drugs such as cocaine alters conscience and the affected person does not perceive the severity of self-impairment.

The psychological domain, according to the instrument used, encompassed self-esteem, spirituality, religion, personal beliefs, thought, learning memory capacity and concentration, where this domain was considered impaired among cocaine dependents. The sequels of chronic abusive use of cocaine are not restricted to the physical domain, where cocaine can also impair thought, memory, pragmatism and result in a reduction of self-esteem, with consequent impairment of the psychological domain. It generally starts with the psychological mechanisms of rationalization, denial and self-deception as mechanisms of reducing the consequences of cocaine abuse.

Similar results to those in our cocaine dependents have been observed in patients with chronic diseases such as renal insufficiency, in which there is QL impairment in physical, psychological and social relations domains ${ }^{9,10}$.

Cocaine is a drug that impairs social relations due to isolation and the use itself and leads to deterioration in the social relations domain. However, despite these difficulties in social relations, the subjects of the present sample studied did not report significant impairment in the QL for the environment domain. We may suppose that these persons did not find major difficulties in the home environment, physical safety, protection, financial resources or in leisure opportunities because these were provided by parents. This may be a characteristic specific of this sample studied because we assessed privately and third party funded inpatients.

In conclusion, sleep impairment in the control group was not correlated to QL because the subjects in this group were generally good sleepers. However, for the cocaine dependent group, sleep impairment was not regarded as compromising QL probably because cocaine, rather than sleep, was the main factor negatively influencing QL. In this patients group, cocaine severely impairs physical, psychological a social relations domains.

\section{REFERENCES}

1. Stein MH, Herman DS, Bishop S, et al. Sleep disturbances among methadone maintained patients. J Subst Abuse Treat 2004;26:175-180.

2. Ventegodt S, Merrick J. Psychoactive drugs and quality of life. Sci World J 2003;3:694-706.

3. International Classification of Sleep Disorders. Diagnostic and Coding Manual. $2^{\text {nd }}$ edition. Westchester, IL: American Academy of Sleep Medicine, 2005

4. ICD-X. International Statistical Classification of Diseases and Related Health Problems. New York, WHO: World Health Organization. 1990.

5. ANEP. Associação Nacional de Empresas de Pesquisas. Dados com base no levantamento sócio econômico. São Paulo: IBOPE, 2000.

6. Buysse DJ, Reynolds CF, Monk TH, Hoch CC, Berman SR, Kupfer DJ. The Pittsburgh Sleep Quality Index: a new instrument for psychiatric practice and research. Psychiatry Res 1988;28:193-213.

7. Fleck MPA. Aplicação em português do instrumento abreviado de avaliação de qualidade de vida WHOQOL-Breve. Rev Saúde Pública 2000;34:178-183.

8. Fleck MPA, Leal OF, Louzada S, et al. Desenvolvimento e aplicação da versão em português do instrumento de avaliação de qualidade de vida da Organização Mundial da Saúde (WHOQOL-100). Rev HCPA 1999;19:9-30

9. Iliescu EA, Côo H, McMurray MH, et al. Quality of sleep and healthrelated quality of life in haemodialysis patients. Nephrol Dial Transplant 2003;18:126-132.

10. Katz DA, McHorney CA. The relationship between insomnia and health-related quality of life in patients with chronic illness. J Fam Pract 2002;51:229-235. 